ORIGINAL ARTICLE

\title{
Hydrogen peroxide as a mitigation of salt stress on the germination of Myracroduon urundeuva (Allemão) Engl. Seeds
}

\author{
Peróxido de hidrogênio como atenuante do estresse salino na germinação de \\ sementes de Myracroduon urundeuva (Allemão) Engl.
}

Marília Hortência Batista Silva Rodrigues ${ }^{1}$ (D), Joyce Naiara da Silva ${ }^{1}$ (D), Edna Ursulino Alves ${ }^{1}$ (i), Riselane de Lucena Alcantara Bruno ${ }^{1}$ (D)

${ }^{1}$ Universidade Federal da Paraíba - UFPB, Areia, PB, Brasil

How to cite: Rodrigues, M. H. B. S., Silva, J. N., Alves, E. U., \& Bruno, R. L. A. (2021). Hydrogen peroxide as a mitigation of salt stress on the germination of Myracroduon urundeuva (Allemão) Engl. Seeds. Scientia Forestalis, 49(130), e3557. https://doi.org/10.18671/scifor.v49n130.14

\begin{abstract}
In this research, the objective was to evaluate the effect of different concentrations of hydrogen peroxide as a mitigation of salt stress on the germination of Myracrodruon urundeuva A. seeds. The work was performed at the Seed Analysis Laboratory of the Agricultural Sciences Center of the Federal University of Paraíba. The concentrations of hydrogen peroxide $\left(\mathrm{H}_{2} \mathrm{O}_{2}\right)$ used were as follows: $0.0 ; 7.0 ; 14.0 ; 21.0$ and $28.0 \mu \mathrm{mol} \mathrm{L}{ }^{-1}$, while saline levels were of $0.0 ; 2.5 ; 5.0 ; 7.5$ and $10.0 \mathrm{dS} \mathrm{m}^{-1}$ prepared from the addition of $\mathrm{NaCl}$ to distilled water $\left(0.0 \mathrm{dS} \mathrm{m}^{-1}\right)$. The experiment was carried out in a completely randomized design, with a $5 \times 5$ factorial scheme, whose evaluated characteristics were germination and vigor (first count, average time and germination speed index, as well as length and shoot dry weight, roots and total seedlings). The concentrations of 7.0 and $14.0 \mu \mathrm{mol} \mathrm{L}^{-1}$ of hydrogen peroxide attenuate the negative effect caused by the salinity level of up to $3.2 \mathrm{dS} \mathrm{m}^{-1}$; however, excessive concentrations of hydrogen peroxide cause damage to the germination process of $M$. urundeuva seeds.
\end{abstract}

Keywords: Aroeira-do-sertão; $\mathrm{H}_{2} \mathrm{O}_{2}$; Physiological quality; Salinity.

\section{Resumo}

Nesta pesquisa o objetivo foi avaliar o efeito de diferentes concentrações de peróxido de hidrogênio como atenuante do estresse salino na germinação de sementes de Myracrodruon urundeuva. O trabalho foi realizado no Laboratório de Análise de Sementes do Centro de Ciências Agrárias da Universidade Federal da Paraíba. As concentrações de peróxido de hidrogênio $\left(\mathrm{H}_{2} \mathrm{O}_{2}\right)$ utilizadas foram as seguintes: 0,$0 ; 7,0 ; 14,0 ; 21,0$ e $28,0 \mu \mathrm{mol} \mathrm{L}^{-1}$, enquanto os níveis salinos de 0,$0 ; 2,5 ; 5,0 ; 7,5$ e $10.0 \mathrm{dS} \mathrm{m}^{-1}$ preparados a partir da adição de $\mathrm{NaCl}$ a água destilada $\left(0,0 \mathrm{dS} \mathrm{m}^{-1}\right)$. $\mathrm{O}$ experimento foi conduzido em delineamento inteiramente ao acaso, com esquema fatorial $5 \times 5$, cujas características avaliadas foram a germinação e o vigor (primeira contagem, tempo médio e índice de velocidade de germinação, bem como comprimento e massa seca da parte aérea, raízes e total das plântulas). As concentrações de 7,0 e $14,0 \mu \mathrm{mol} \mathrm{L}^{-1}$ de peróxido de hidrogênio atenuam o efeito negativo causado pelo nível de salinidade de até $3,2 \mathrm{dS} \mathrm{m}^{-1}$; no entanto, concentrações excessivas de peróxido de hidrogênio causam prejuízos ao processo germinativo de sementes de $M$. urundeuva.

Palavras-chave: Aroeira do sertão; Salinidade; $\mathrm{H}_{2} \mathrm{O}_{2}$; Qualidade fisiológica; Vigor.

Financial support: Coordenação de Aperfeiçoamento de Pessoal de Nível Superior - CAPES (Graduate Program Scholarship). The process number does not apply.

Conflict of interest: Nothing to declare.

Correspondig author: marilia_agroecologa@hotmail.com

Received: 8 June 2020.

Accepted: 18 August 2020.

Editor: Paulo Henrique Müller Silva.

(c) (i) This is an Open Access article distributed under the terms of the Creative Commons Attribution License, which permits unrestricted use,

c) distribution, and reproduction in any medium, provided the original work is properly cited. 


\section{INTRODUCTION}

The growing stimulus for the regeneration of degraded areas along with the forest remnants has generated a demand for the implementation of projects for the insertion of native tree species in agroforestry plantations, forest restoration and rehabilitation of degraded lands (Costa et al., 2015). This increases the demand for quality forest seedlings, but the quality of the water used in irrigation may be a limiting factor, since most of the water used by farmers in the Northeast comes from surface reservoirs that contain a high content of dissolved salts, which may affect plant development (Oliveira et al., 2015).

The period in which the seeds will germinate is essential for the survival of forest species, especially in environments where water availability is limited, as in the Caatinga (Braga et al., 2009). The germination process begins with the absorption of water by imbibition, however, when there is excess salt in the substrate, absorption restriction occurs, due to the decrease in its osmotic potential (Marcos Filho, 2015). The excess of salts may alter the biochemical and physiological functions of plants, so that osmotic stress will trigger disturbances in water relations, changes in the absorption and use of essential nutrients, in addition to the accumulation of toxic ions (Diniz et al., 2018).

Recently, the use of hydrogen peroxide $\left(\mathrm{H}_{2} \mathrm{O}_{2}\right)$ for inducing stress tolerance has been frequent, due to its importance in physiological processes and its action as a stress-signaling molecule (Niu \& Liao, 2016; Amooaghaie \& Tabatabaie, 2017). The main mechanisms induced by $\mathrm{H}_{2} \mathrm{O}_{2}$ involve interactions with germination-controlling hormones and a significant increase in enzymatic and non-enzymatic antioxidants, which play a defensive role against oxidative stress (Ben Rejeb et al., 2014; Guler \& Pehlivan, 2016; Talbi et al., 2015; Javed et al., 2018).

The application of $\mathrm{H}_{2} \mathrm{O}_{2}$ in low concentrations acts as a signaling molecule and, although it may be quickly removed by antioxidant enzymes, in concentrations around 1-10 mM, the elimination mechanisms are less effective, allowing it to act as a flag (Sies, 2017; Černý et al., 2018).

In general, a pre-treatment with $\mathrm{H}_{2} \mathrm{O}_{2}$ increases the capacity of the antioxidant system of the plants, which quickly acts on the ROS (reactive oxygen species) resulting from stress, neutralizing the action or preventing their generation, producing lower concentrations of ROS and, consequently, less cell damage and greater survival in such conditions (Li et al., 2011).

Myracrodruon urundeuva (Allemão) Engl. (Anacardiaceae) is a tree species native to Brazil, which occurs abundantly in the Caatinga region, where it is popularly known as aroeira, aroeira-do-cerrado and aroeira-do-sertão (Lorenzi, 2008; Pereira et al., 2014). The species is important due to the use of its wood, in addition to the potential for use by the pharmacological industries, due to its anti-inflammatory, astringent, anti-allergic and healing properties (Canuto et al., 2016). However, the growing and unrestrained environmental exploitation has threatened several forest species such as $M$. urundeuva.

Considering that the seed is an input that guarantees and ensures the conservation and perpetuation of species that are at risk of extinction, information on the behavior of these seeds subjected to abiotic stresses is of paramount importance. In view of this, the objective was to evaluate the effect of hydrogen peroxide as a mitigation of salt stress on the germination and vigor of $M$. urundeuva seeds.

\section{MATERIALS AND METHODS}

\section{Experiment location}

The work was performed at the Seed Analysis Laboratory of the Agricultural Sciences Center of the Federal University of Paraíba, Areia, PB, with seeds of $M$. urundeuva, from the Nucleus of Ecology and Environmental Monitoring of Petrolina, Pernambuco.

The harvest was performed in seed trees between the end of September and the beginning of October 2018, in the town of Salgueiro - PE $\left(8^{\circ} 03^{\prime} 28^{\prime \prime} \mathrm{S}\right.$ and $39^{\circ} 05^{\prime} 45^{\prime \prime} \mathrm{W}$; altitude $511 \mathrm{~m}$ ). The processing was performed manually with the use of a sieve, between October and November 2018. Subsequently, the diaspores were conditioned in a transparent plastic bag, and kept in ambient condition until May 2019, when the experiment was started. 


\section{Experimental design}

The experiment was designed in a completely randomized design, with the treatments distributed in a $5 \times 5$ factorial scheme, corresponding to concentrations of hydrogen peroxide $-\mathrm{H}_{2} \mathrm{O}_{2}\left(\mathrm{H}_{1}: 0.0 ; \mathrm{H}_{2}\right.$ : 7.0; $\mathrm{H}_{3}: 14.0 ; \mathrm{H}_{4}: 21.0$ and $\left.\mathrm{H}_{5}: 28.0 \mu \mathrm{mol} \mathrm{L}^{-1}\right)$ and salinity levels $(0.0 ; 2.5 ; 5.0$; 7.5 and $\left.10.0 \mathrm{dS} \mathrm{m}^{-1}\right)$.

\section{Preparation and application of treatments}

Hydrogen peroxide $\left(\mathrm{H}_{2} \mathrm{O}_{2}\right)$ solutions were prepared from the dilution of peroxide $(35 \%)$ in the respective pre-established concentrations (0.0; 7.0; 14.0; 21.0 and $28.0 \mu \mathrm{mol} \mathrm{L}^{-1}$ ). The application was performed before the sowing of the seeds, which were soaked in the solution for 24 hours.

Saline solutions $\left(0.0,2.5,5.0,7.5\right.$ and $\left.10.0 \mathrm{dS} \mathrm{m}^{-1}\right)$ were prepared with deionized water and the concentration of salts obtained from the Van't Hoff equation, cited by Salisbury \& Ross (1992); Braccini et al. (1996); Taiz et al. (2017).

\section{Characteristics analyzed}

Germination percentage (GP): the seeds were sown on two towel sheets (Germitest ${ }^{\circledR}$ ), covered with a third leaf, moistened with the pre-established saline solutions in the proportion of 2.5 times the weight of the dry substrate, using four repetitions of 25 seeds, totaling 100 seeds, per treatment. These were stored in a germination chamber of the type Biological Oxygen Demand (B.O.D.) at a temperature of $25^{\circ} \mathrm{C}$ with a photoperiod of 12 hours, for 15 days (Brasil, 2009). The evaluations were performed from seven to 15 days after sowing, with the results expressed as an average percentage of normal seedlings for each treatment.

First germination count (FGC): was performed together with the germination test, whose values of the first germination count were acquired by determining the percentage of normal seedlings on the seventh day after sowing and the results were expressed as a percentage (\%).

Average germination time (AGT): the seeds incubated in the previous conditions for the germination test, were evaluated daily from the third day to the fifteenth day after sowing. The results were expressed in days, using the formula of Edmond \& Drapalla (1958).

Germination speed index (GSI): concomitantly to the germination test, daily counts were performed at the same time, for 15 days, of the number of normal seedlings. The index was calculated according to the equation proposed by Maguire (1962).

Seedling length: the length of the shoot, root and total was determined with the aid of a ruler graduated in millimeters and the results were expressed in centimeters.

Seedlings dry weight: the seedlings of the previous evaluation, separated in shoot, roots and total, were placed in kraft paper bags, separated by replication, previously identified and dried in a regulated oven at $65^{\circ} \mathrm{C}$, until reaching constant weight (48 hours) and, after this period, the samples were weighed on an analytical balance with an accuracy of $0.001 \mathrm{~g}$, with all results expressed in grams.

\section{Data analysis}

The data were submitted to analysis of variance (ANOVA) and the averages were submitted to regression analysis using the Sisvar software, Version 5.6 (Ferreira, 2014).

\section{RESULTS AND DISCUSSION}

In the analysis of variance regarding the germination percentage, first count, speed index and average germination time of $M$. urundeuva seeds, there was a significant effect $(p<0.05)$ when the seeds were submitted to different concentrations of hydrogen peroxide and salinity levels, demonstrating that both factors evaluated simultaneously affect seed germination and vigor (Table 1). 
Table 1. Analysis of variance of the germination percentage (GP), first count (GFC), speed index (GSI) and average germination time (AGT) of Myracrodruon urundeuva seeds submitted to different concentrations of hydrogen peroxide and salinity levels.

\begin{tabular}{|c|c|c|c|c|c|}
\hline \multirow{2}{*}{ VS } & \multirow{2}{*}{ GL } & \multicolumn{4}{|c|}{ Medium squares } \\
\hline & & GP (\%) & GFC (\%) & GSI & AGT $\left(\right.$ days $\left.^{-1}\right)$ \\
\hline Peroxide $(P)$ & 4 & $139111.20 * \star$ & 817.40 ** & $45.63^{* \star}$ & $9.75^{* *}$ \\
\hline Salinity (S) & 4 & $4014.20 * \star$ & $218.90 * *$ & $18.06 * \star$ & $9.28 * *$ \\
\hline$P \times S$ & 16 & $324.15^{* *}$ & $25.30 * \star$ & $1.34 * \star$ & $0.26 * *$ \\
\hline Residue & 75 & 10.38 & 1.98 & 0.03 & 0.081 \\
\hline Total & 99 & & & & \\
\hline VC (\%) & & 5.70 & 12.93 & 5.71 & 5.03 \\
\hline
\end{tabular}

** significant to $1 \%(\mathrm{p}<0.01)$; VS: variation source; VC: variation coefficient.

At hydrogen peroxide concentrations of $0.0\left(\mathrm{H}_{1}\right)$ and $21.0 \mu \mathrm{mol} \mathrm{L} \mathrm{L}^{-1}\left(\mathrm{H}_{4}\right)$, the estimated minimum germination percentage was 41 and $23 \%$ at the salinity levels of 10.0 and $9.4 \mathrm{dS} \mathrm{m}^{-1}$, respectively, while at the concentration of $7.0 \mu \mathrm{mol} \mathrm{L}^{-1}\left(\mathrm{H}_{2}\right)$, a maximum germination percentage of $91 \%$ was found at the salinity level of $1.4 \mathrm{dS} \mathrm{m}^{-1}$, characterizing that this treatment reduced the deleterious effects caused by the excess of salts. The concentrations of $14.0\left(\mathrm{H}_{3}\right)$ and $28.0 \mu \mathrm{mol} \mathrm{L}-1\left(\mathrm{H}_{5}\right)$ provided a reduction of 30 and $47 \%$, respectively in germination due to the increase in salinity levels (Figure $1 \mathrm{~A}$ ).
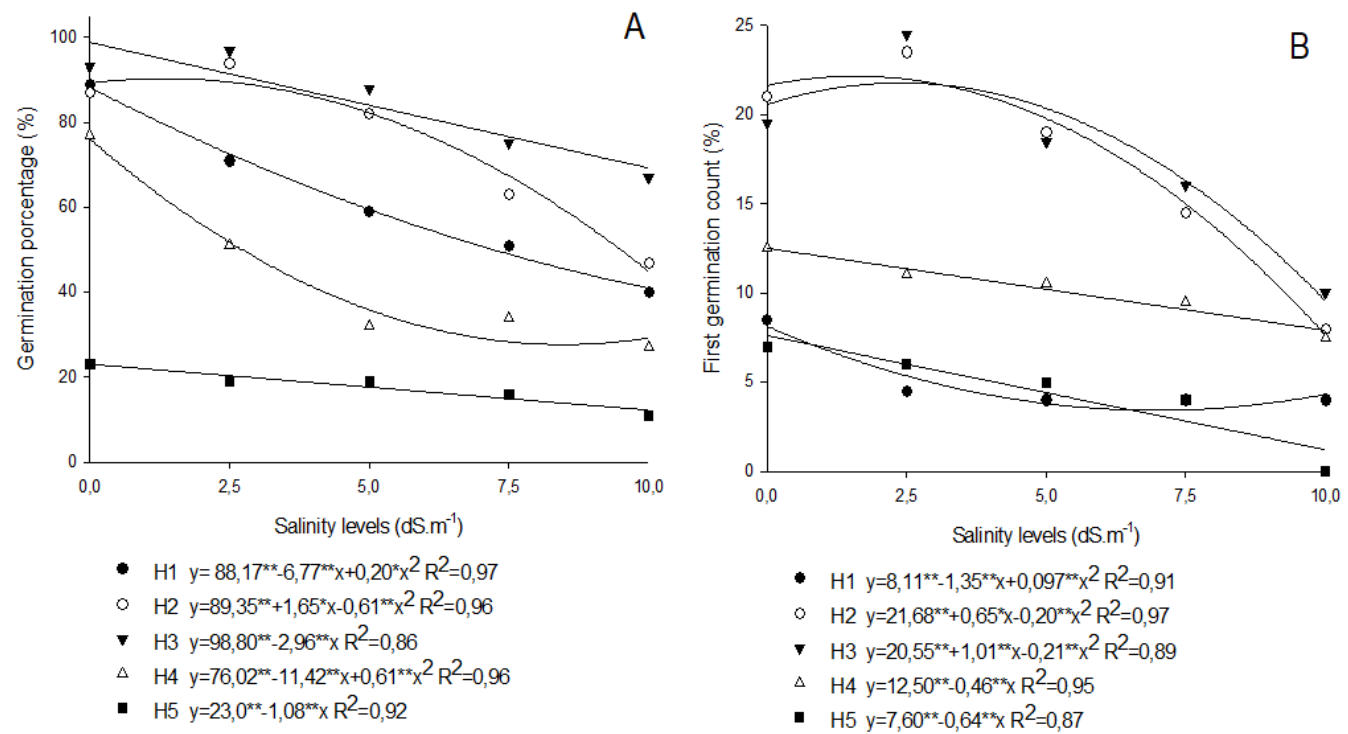

Figure 1. Germination percentage (A) and first germination counting (B) of Myracrodruon urundeuva seeds submitted to different concentrations of hydrogen peroxide $(\mathrm{H} 1: 0.0 ; \mathrm{H} 2: 7.0 ; \mathrm{H} 3: 14.0 ; \mathrm{H} 4: 21.0$ and $\mathrm{H} 5: 28.0 \mu \mathrm{mol} \mathrm{L}^{-1}$ ) and salinity levels.

Concentrations above $14.0 \mu \mathrm{mol} \mathrm{\textrm {L } ^ { - 1 }}$ cause a reduction in the germination percentage in Medicago sativa seeds, due to the increase in salinity levels, thus evidencing a double role of hydrogen peroxide, which is a signal in low concentrations, as well as may cause oxidative damage in high concentration (Amooaghaie \& Tabatabaie, 2017).

In the research by Oliveira et al. (2014), the germination percentage of $M$. urundeuva seeds in the electrical conductivity $2 \mathrm{dS} \mathrm{m}^{-1}$ was 70\%, with a subsequent reduction in this percentage, in which from $14 \mathrm{dS} \mathrm{m}^{-1}$ there was a total absence of germination.

The data of the first germination count of the seeds submitted to concentrations of hydrogen peroxide of $7.0\left(\mathrm{H}_{2}\right)$ and $14.0 \mu \mathrm{mol} \mathrm{L} \mathrm{L}^{-1}\left(\mathrm{H}_{3}\right)$ adjusted to the quadratic model, reaching a maximum estimated value of $22 \%$ at salinity levels of 2.7 and $2.6 \mathrm{dS} \mathrm{m} \mathrm{m}^{-1}$, respectively. The $0.0 \mu \mathrm{mol} \mathrm{L}^{-1}\left(\mathrm{H}_{1}\right)$ 
concentration data also adjusted to the quadratic model, however negative, with an estimated minimum value of $3 \%$ at the salinity level of $7.0 \mathrm{dS} \mathrm{m}^{-1}$. The treatment data with concentrations of $21.0\left(\mathrm{H}_{4}\right)$ and $28.0 \mu \mathrm{mol} \mathrm{L} \mathrm{L}^{-1}\left(\mathrm{H}_{5}\right)$ adjusted to the decreasing linear equation, with a reduction of 37 and $61 \%$, respectively, between the salinity levels of 0.0 and $10.0 \mathrm{dS} \mathrm{m}^{-1}$ (Figure 1B).

The results observed in the concentrations of $7.0\left(\mathrm{H}_{2}\right)$ and $14.0 \mu \mathrm{mol} \mathrm{L}^{-1}\left(\mathrm{H}_{3}\right)$ are related to the main mechanisms induced by hydrogen peroxide, which involve interactions with germination-controlling hormones and a significant increase in enzymatic and non-enzymatic antioxidants, which play a defensive role against oxidative stresses (Ben Rejeb et al., 2014; Guler \& Pehlivan, 2016; Talbi et al., 2015; Javed et al., 2018). However, with the increase in salinity levels, there was a reduction in the attenuating effects of hydrogen peroxide, characterizing that both treatments may negatively affect the performance of seeds when in high concentrations.

When assessing the potential of hydrogen peroxide as a mitigation of salt stress in germination and initial growth of barley, Kilic \& Kahraman (2016) demonstrated a reduction in the deleterious effects caused by excess salts in this species, especially when the concentration was $30 \mu \mathrm{mol} \mathrm{L} \mathrm{L}^{-1}$ was used.

Analyzing the germination speed index of $M$. urundeuva seeds, a quadratic trend was found for the concentrations of $0.0\left(\mathrm{H}_{1}\right)$ and $21.0 \mu \mathrm{mol} \mathrm{L} \mathrm{L}^{-1}\left(\mathrm{H}_{4}\right)$ of hydrogen peroxide, with an estimated minimum value of 1.94 and 1.52, both at the salinity level of $10.0 \mathrm{dS} \mathrm{m}^{-1}$, while at the concentration of $14.0 \mu \mathrm{mol} \mathrm{L}{ }^{-1}\left(\mathrm{H}_{3}\right)$, an estimated maximum of 5.63 was obtained at the salinity level of $1.4 \mathrm{dS} \mathrm{m}^{-1}$, proving the efficiency of hydrogen peroxide in reducing salt stress. The seeds submitted to concentrations of $7.0\left(\mathrm{H}_{2}\right)$ and $28.0 \mu \mathrm{mol} \mathrm{L}-1\left(\mathrm{H}_{5}\right)$ gradually reduced the germination speed index as the saline level of the water increased, this reduction being 55 and $47.8 \%$, respectively, between salinity levels from 0.0 to $10.0 \mathrm{dS} \mathrm{m}^{-1}$ (Figure 2A).

A

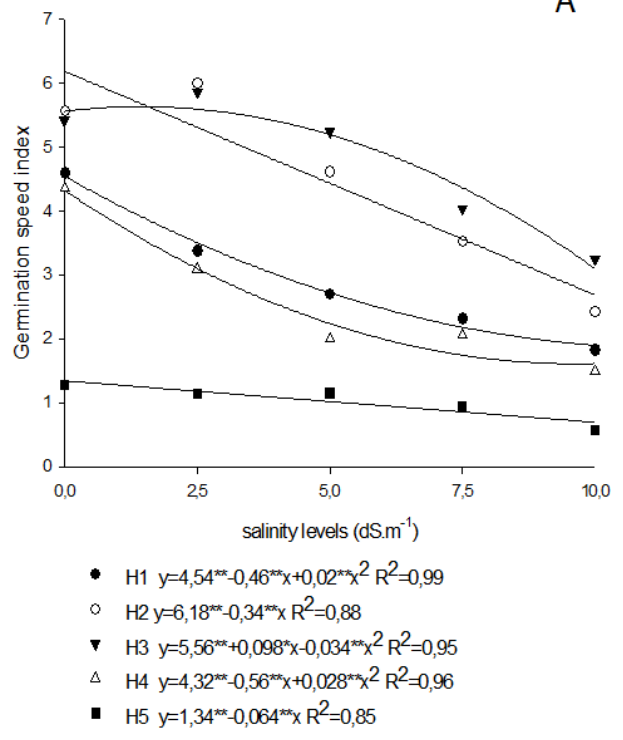

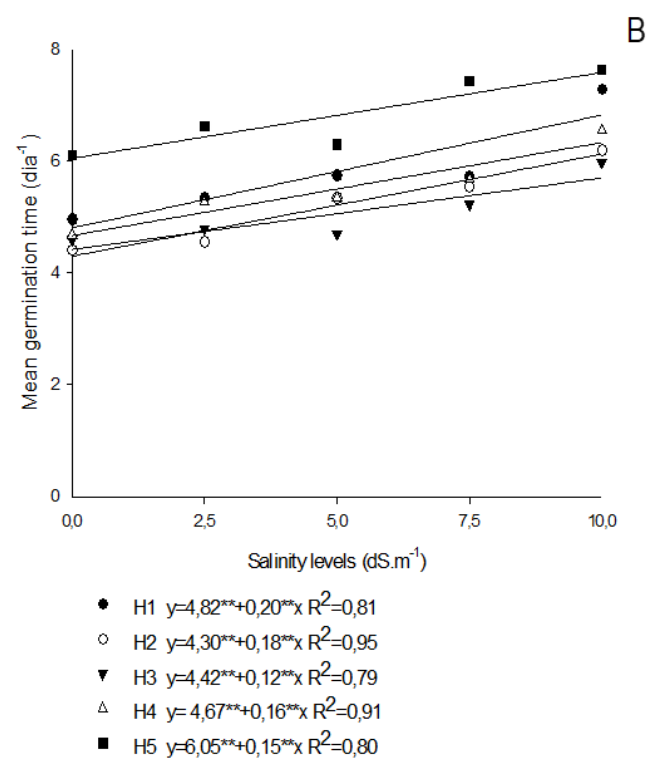

Figure 2. Index of germination speed (A) and medium time of germination (B) of Myracrodruon urundeuva seeds submitted to different concentrations of hydrogen peroxide $(\mathrm{H1}$ : 0.0; H2: 7.0; H3: 14.0; $\mathrm{H} 4: 21.0$ and $\mathrm{H} 5: 28.0 \mu \mathrm{mol} \mathrm{L} \mathrm{L}^{-1}$ ) and salinity levels.

Hydrogen peroxide produced during germination by mitochondrial respiratory activity ( $\beta$-oxidation) and by the action of enzymes such as NADPH oxidases, extracellular peroxidases and oxalates oxidases, helps in mobilizing reserves for the rapid growth of the embryonic axis (Verma et al., 2015; Wojtyla et al., 2016), probably has increased the germination speed index of $M$. urundeuva seeds to the salinity level of $2.5 \mathrm{dS} \mathrm{m} \mathrm{m}^{-1}$ in the treatments of $7.0\left(\mathrm{H}_{2}\right)$ and $14.0 \mu \mathrm{mol} \mathrm{L}^{-1}\left(\mathrm{H}_{3}\right)$ of hydrogen peroxide in the present research.

In an experiment performed with soybean seeds treated with different concentrations (control, 50, 100 and $200 \mathrm{mM}$ ) of hydrogen peroxide produced and subjected to saline stress 
( $\mathrm{NaCl}-0.2 \mathrm{MPa}$ ), Oliveira (2019) observed that there was no significant difference between treatments for speed index and percentage of germination. On the other hand, it was observed that, regarding the seedling vigor index, the $10 \mathrm{mM}$ concentration promoted greater vigor when compared to the other treatments.

The behavior of the data regarding the average germination time of $M$. urundeuva seeds was linear for all concentrations of hydrogen peroxide evaluated, with an increase of 29.3, 29.5, 21.3, 25.5 and 19.8\% between the first and the last salt level evaluated (Figure 2B). Salinity reduces water potential; consequently, there is a reduction in cellular and metabolic activities, resulting in an increase in the time of the germination process (Taiz et al., 2017).

For the results of the analysis of variance for the variables of length and root dry weight and total shoot, seedlings dry weight from $M$. urundeuva seeds submitted to different concentrations of hydrogen peroxide and levels of salinity, it was found that there was a significant effect for all variables evaluated as a result of these treatments (Table 2).

Table 2. Analysis of variance of the length and Dry weight of the aerial part (LAP and MDAP), of the roots (LR and MDR) and total (CT and MDT) of Myracrodruon urundeuva seeds submitted to different concentrations of hydrogen peroxide and salinity levels.

\begin{tabular}{|c|c|c|c|c|c|c|c|}
\hline \multirow{3}{*}{ VS } & \multirow{3}{*}{ GL } & \multicolumn{6}{|c|}{ Medium squares } \\
\hline & & LAP & LR & LT & MDAP & MDR & MDT \\
\hline & & \multicolumn{3}{|c|}{$\mathrm{cm}$} & \multicolumn{3}{|c|}{ g } \\
\hline Peroxide $(P)$ & 4 & $2.85^{* *}$ & $2.78 * \star$ & $9.88^{* *}$ & $1.4 \times 10^{-3 * *}$ & $4.7 \times 10^{-5 * \star}$ & $2.059 \times 10^{-3 * *}$ \\
\hline Salinity (S) & 4 & $5.24 * *$ & $7.93 * \star$ & $25.79 * *$ & $2.6 \times 10^{-4 * *}$ & $4.1 \times 10^{-5 \star \star}$ & $4.84 \times 10^{-4 \star \star}$ \\
\hline$P \times S$ & 16 & $0.57 * \star$ & $0.89 * \star$ & $2.25^{\star \star}$ & $9.5 \times 10^{-5 \star *}$ & $6 \times 10^{-6 \star \star}$ & $1.38 \times 10^{-4 \star \star}$ \\
\hline Residue & 75 & 0.07 & 0.07 & 0.14 & $2 \times 10^{-6}$ & $7.21 \times 10^{-8}$ & $2 \times 10^{-6}$ \\
\hline Total & 99 & & & & & & \\
\hline VC (\%) & & 12.41 & 16.17 & 9.81 & 18.13 & 9.30 & 14.05 \\
\hline
\end{tabular}

** significant to $1 \%(p<0.01)$; VS: variation source; VC: variation coefficient.

The data on the shoot length of the seedlings of $M$. urundeuva was adjusted to a linear model, with a reduction of 15.9, 52.4, 55.5, 40.2 and $39.2 \%$ between saline levels of 0.0 and $10.0 \mathrm{dS} \mathrm{m}^{-1}$ (Figure 3A).In this type of stress salinity causes osmotic stress and, consequently, water deficit, which is directly related to the growth of plants due to the functions performed by water, such as the ability to solubilize essential elements for development, facilitating its mobility within the plant and for being a medium that governs various chemical reactions that occur in plants (Taiz et al., 2017).

In the length of the seedling root, a decreasing linear behavior was also observed, due to the increase in salinity levels, characterized by a reduction of $67.07,74.4$ and $45 \%$ in the concentrations of $\left(\mathrm{H}_{1}: 0.0 ; \mathrm{H}_{2}: ; \mathrm{H}_{3}: ; \mathrm{H}_{4}: 21.0\right.$ and $\left.\mathrm{H}_{5}:\right) 7.0\left(\mathrm{H}_{2}\right), 14.0\left(\mathrm{H}_{3}\right)$ and $28.0 \mu \mathrm{mol} \mathrm{L}^{-1}\left(\mathrm{H}_{5}\right)$, respectively, between the highest and lowest assessed salt levels. The data for the concentrations of $0.0\left(\mathrm{H}_{1}\right)$ and $7.0\left(\mathrm{H}_{2}\right)$ adjusted to the quadratic model, with a gradual reduction as the levels of salts increased, reaching an estimated minimum 1.15 and $0.17 \mathrm{~cm}$, both observed at the salinity level of $10.0 \mathrm{dS} \mathrm{m}^{-1}$ (Figure 3B).

Under normal conditions, hydrogen peroxide produced in different parts of the plant, interferes with various physiological processes during all stages of plant development, including accelerating the growth of primary and lateral roots (Hernández-Barrera et al., 2015), which can be seen in Figure $3 \mathrm{~A}$, which at a concentration of $7.0 \mu \mathrm{mol} \mathrm{L}^{-1}\left(\mathrm{H}_{2}\right)$ provided greater length at the salinity level from 0 to $5 \mathrm{dS} \mathrm{m}^{-1}$.

As for the total length of seedlings, it was observed that there was a quadratic behavior at concentrations of $0.0\left(\mathrm{H}_{1}\right)$ and $21.0 \mu \mathrm{mol} \mathrm{L}^{-1}\left(\mathrm{H}_{4}\right)$, with an estimated minimum value of 3.32 and $2.32 \mathrm{~cm}$, at the salinity level of 9.7 and $10.0 \mathrm{dS} \mathrm{m}^{-1}$, respectively. The behavior of the concentrations of $7.0\left(\mathrm{H}_{2}\right), 14.0\left(\mathrm{H}_{3}\right)$ and $28.0 \mu \mathrm{mol} \mathrm{L}^{-1}\left(\mathrm{H}_{5}\right)$ was linear decreasing, with a reduction of $60.8 ; 65.0$ and $38.4 \%$ between the highest and lowest saline levels evaluated, that 
is, as the concentration of salts in the water increased, regardless of the treatment employed, there was a drastic reduction in seedling growth (Figure 3C).
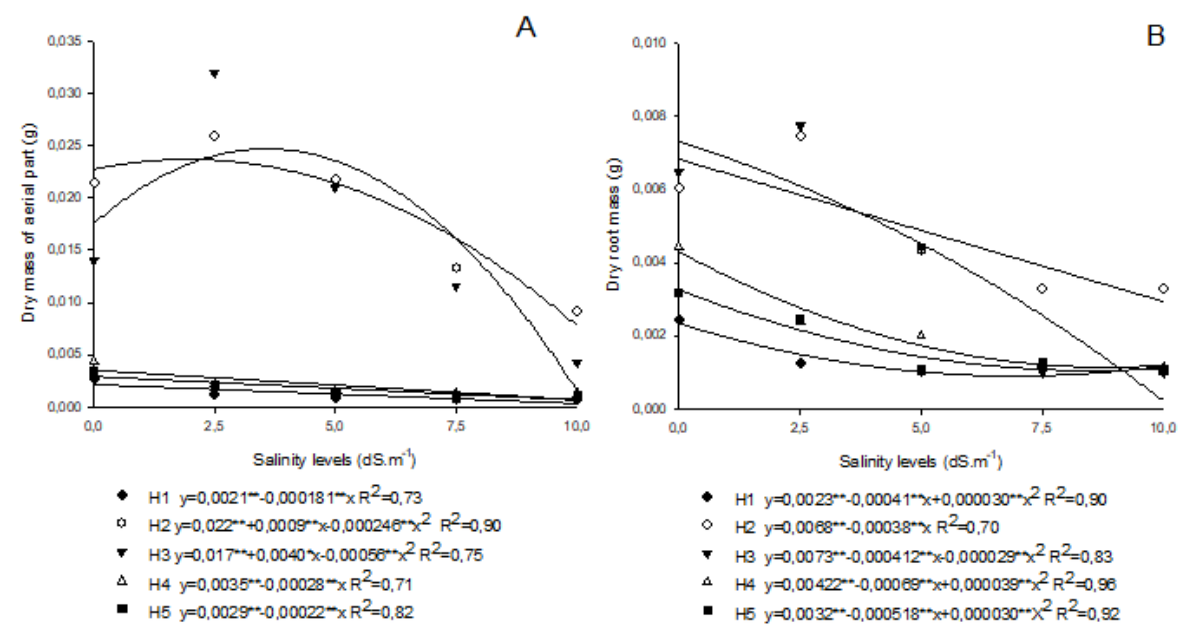

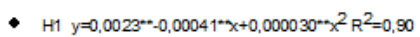

H. $y=0,0068^{* *}-0,00038^{*} \times R^{2}=0,70$

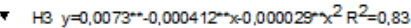

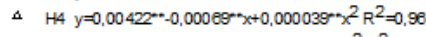

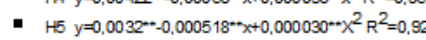

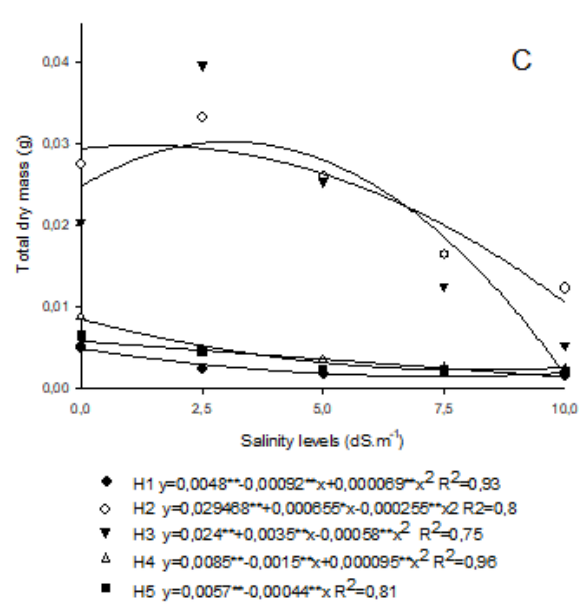

Figure 3. Length of the aerial part (A), root (B) and total (C) of Myracrodruon urundeuva seeds submitted to different concentrations of hydrogen peroxide $(\mathrm{H} 1$ : 0.0; $\mathrm{H} 2$ : 7.0; H3: 14.0; H4: 21.0 and $\mathrm{H} 5: 28.0 \mu \mathrm{mol} \mathrm{L}^{-1}$ ) and salinity levels.

The accumulation of $\mathrm{Na}^{+}$and $\mathrm{Cl}^{-}$ions causes protoplasm to swell, affecting enzyme activity and causing quantitative and qualitative changes in metabolism. Consequently, a reduction in energy production occurs as well as the formation of disturbances in the assimilation of nitrogen, changes in the pattern of amino acids and in the metabolism of proteins; all factors that may compromise the growth and development of the plant (Lucchese et al., 2018).

From the data in Figure 4A, it can be seen that the concentrations of $7.0\left(\mathrm{H}_{2}\right)$ and $14.0 \mu \mathrm{mol} \mathrm{L}-1\left(\mathrm{H}_{3}\right)$ provided a gradual increase, reaching maximum values estimated at 0.022 and $0.024 \mathrm{~g}$ at the salinity level of 2.3 and $3.9 \mathrm{dS} \mathrm{m}^{-1}$, respectively, followed by a reduction trend in these values, reaching a salinity level of $10.0 \mathrm{dS} \mathrm{m}^{-1}$ with dry weight of 0.0064 and $0.001 \mathrm{~g}$. However, it was also found that in the absence of hydrogen peroxide $\left(\mathrm{H}_{1}\right)$ or high concentrations of 21.0 and $28.0 \mu \mathrm{mol} \mathrm{L}^{-1}\left(\mathrm{H}_{4}\right.$ and $\mathrm{H}_{5}$, respectively), seedling dry weight performance and accumulation was negatively affected, with linear decreasing behavior in these concentrations and a reduction of $85.7,80$ and $75.8 \%$, between salinity levels of 0.0 and $10.0 \mathrm{dS} \mathrm{m}^{-1}$.

High concentrations of $\mathrm{NaCl}$ affect the translocation of the tissue reserve substances from seeds to the embryo and synthesis of hormones from the roots to the shoot, which 
causes a reduction in the leaf area and, consequently, reduces the accumulation of dry weight in the seedling tissues (Schossler et al., 2012).

At concentrations of $0.0\left(\mathrm{H}_{1}\right), 14.0\left(\mathrm{H}_{3}\right), 21.0\left(\mathrm{H}_{4}\right)$ and $28.0\left(\mathrm{H}_{5}\right) \mu \mathrm{mol} \mathrm{L}{ }^{-1}$ of hydrogen peroxide, there was a quadratic behavior, whose estimated minimum values were 0.0009, $0.0003,0.0012$ and $0.001 \mathrm{~g}$ at the salinity level of $8.1 \mathrm{dS} \mathrm{m}^{-1}$, with the latter three concentrations showing minimum accumulation of dry weight of the radicle when subjected to $10.0 \mathrm{dS} \mathrm{m}^{-1}$. In the dry weight of the radicle, it was observed that at the $7.0 \mu \mathrm{mol} \mathrm{L}-1\left(\mathrm{H}_{2}\right)$ concentration the behavior was decreasing linearly, equivalent to a $55.9 \%$ reduction between the lowest and highest analyzed salinity level (Figure 4B).

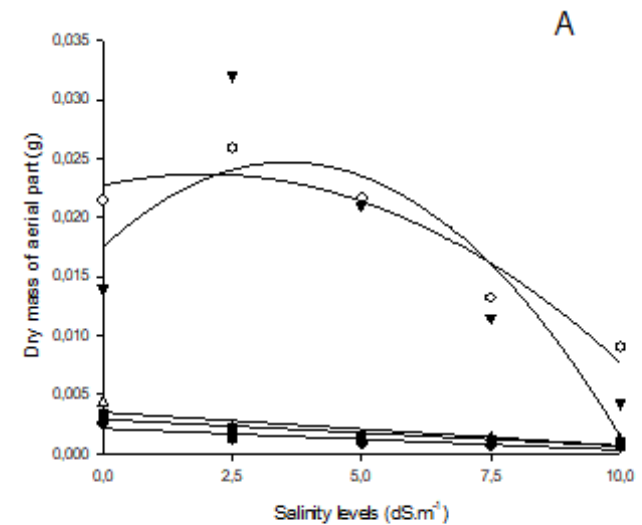

- $H 1 y=0,0021^{-0}-0,000181^{-} x R^{2}=0,73$

- $\mathrm{H} 2 \mathrm{y}=0,022^{-}+0,0009-0,000246-x^{2} R^{2}=0,90$

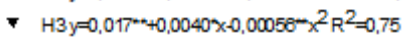

$\triangle \mathrm{H} 4 \mathrm{y}=0,0035^{-}-0,00028^{-} \times R^{2}=0,71$

- $H 5 y=0,0029^{-0,00022-x} \times R^{2}=0,82$

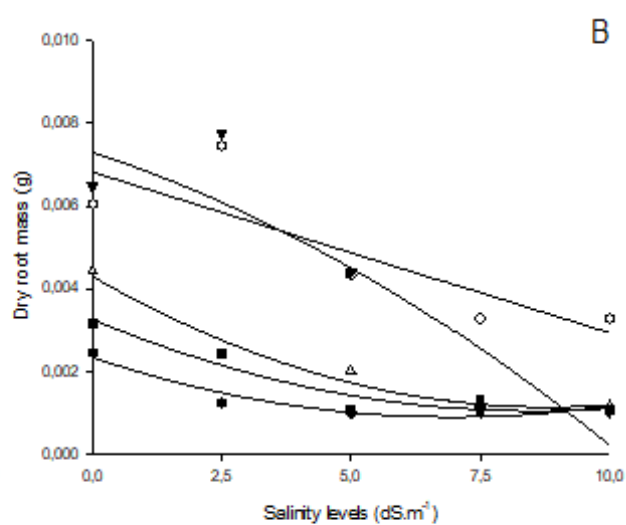

- $H 1 y=0,0023^{-}-0,00041-x+0,000030^{-m} x^{2} R^{2}=0,90$

a $H 2 y=0,0088^{-}-0,00038^{-} \times R^{2}=0,70$

- $H 3$ y $=0,0073^{-}-0,000412-0,0000 e^{-r} x^{2} R^{2}=0,83$

$\triangle \mathrm{H} 4 \mathrm{y}=0,00422 * 0,00089 \mathrm{x}+0,000033^{\circ} x^{2} \mathrm{R}^{2}=0,98$

- $H 5 y=0,0032^{-1}-0,000518^{-m} x+0,000030^{\circ-x^{2}} R^{2}=0,92$

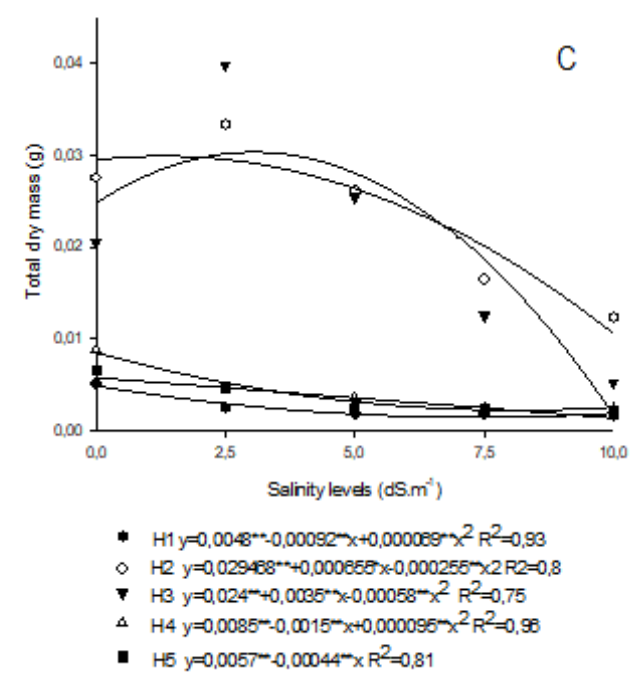

Figure 4. Dry weight of the aerial part (A), roots (B) and total (C) of Myracrodruon urundeuva seeds submitted to different concentrations of hydrogen peroxide $(\mathrm{H} 1: 0.0 ; \mathrm{H} 2$ : 7.0; $\mathrm{H} 3: 14.0 ; \mathrm{H} 4: 21.0$ and $\mathrm{H} 5: 28.0 \mu \mathrm{mol} \mathrm{L}^{-1}$ ) and salinity levels.

The total dry weight followed a decreasing linear effect due to the increase in $\mathrm{NaCl}$ in the water for seeds that were treated only with a concentration of $28.0 \mu \mathrm{mol} \mathrm{L} \mathrm{L}^{-1}\left(\mathrm{H}_{5}\right)$ of hydrogen peroxide, with a reduction of $77.2 \%$, while in the concentrations of $7.0\left(\mathrm{H}_{2}\right)$ and $14.0 \mu \mathrm{mol} \mathrm{L}^{-1}\left(\mathrm{H}_{3}\right)$ the behavior was quadratic, reaching an estimated maximum of $0.029 \mathrm{~g}$ in both salinity levels (1.6 and $3.2 \mathrm{dS} \mathrm{m}^{-1}$, respectively). At concentrations of $0.0\left(\mathrm{H}_{1}\right)$ and $21.0 \mu \mathrm{mol} \mathrm{L}^{-1}\left(\mathrm{H}_{4}\right)$, the behavior 
was also quadratic, with the estimated minimum values of 0.0019 and $0.0026 \mathrm{~g}$ at the salinity level of 8.4 and $8.8 \mathrm{dS} \mathrm{m}^{-1}$, respectively (Figure 4C).

Hydrogen peroxide in high concentrations causes oxidative damage to important cellular metabolites, while at lower concentrations it initiates cell signaling (Gechev \& Hille, 2005; Bhattacharjee, 2012). The redox imbalance associated with environmental stresses, such as salinity and temperature extremes, increases the overall rate of metabolism and eventually increases the production of hydrogen peroxide in plant cells (Bhattacharjee, 2013), which explains the reduction of dry weight accumulation, due to the increase in water salinity in seeds treated with the highest concentration of hydrogen peroxide.

In view of this, it is evident that the use of hydrogen peroxide is an effective alternative for mitigating the effects of excess salts in the seeds, especially in the initial stages that involve the germination of the seeds and consequently in the growth and development of the seedlings.

\section{CONCLUSION}

The concentrations of 7.0 and $14.0 \mu \mathrm{mol} \mathrm{L}^{-1}$ of hydrogen peroxide attenuate the negative effect caused by salinity to $3.2 \mathrm{dS} \mathrm{m}^{-1}$ on the germination and vigor of $M$. urundeuva seeds. Hydrogen peroxide in high concentrations reduces and is harmful to the germination process of $M$. urundeuva seeds. High concentrations of salts $(\mathrm{NaCL})$ compromise the physiological quality of $M$. urundeuva seeds.

\section{REFERENCES}

Amooaghaie, R., \& Tabatabaie, F. (2017). Osmopriming-induced salt tolerance during seed germination of alfalfa most likely mediates through $\mathrm{H} 2 \mathrm{O} 2$ signaling and upregulation of heme oxygenase. Protoplasma, 254(4), 1791-1803. http://dx.doi.org/10.1007/s00709-016-1069-5.

Ben Rejeb, K., Abdelly, C., \& Savouré, A. (2014). How reactive oxygen species and proline face stress together. Plant Physiology and Biochemistry, 80, 278-284. PMid:24813727. http://dx.doi.org/10.1016/j.plaphy.2014.04.007.

Bhattacharjee, S. (2012). An inductive pulse of hydrogen peroxide pretreatment restores redoxhomeostasis and oxidative membrane damage under extremes of temperature in two rice cultivars. Plant Growth Regulation, 68, 395-410. http://dx.doi.org/10.1007/s10725-012-9728-9.

Bhattacharjee, S. (2013). Heat and chilling induced disruption of redox homeostasis and its regulation by hydrogen peroxide in rice (Oryza sativa L., Cultivar Ratna). Physiology and Molecular Biology of Plants, 19(2), 199-207. PMid:24431487. http://dx.doi.org/10.1007/s12298-012-0159-x.

Braccini, A. L., Ruiz, H. A., Braccini, M. C. L., \& Reis, M. S. (1996). Germinação e vigor de sementes de soja sob estresse hídrico induzido por soluções de cloreto de sódio, manitol e polietileno glicol. Revista Brasileira de Sementes, 18(1), 10-16. http://dx.doi.org/10.17801/0101-3122/rbs.v18n1p10-16.

Braga, L. F., Sousa, M. P., \& Almeida, T. A. (2009). Germinação de sementes de Enterolobium schomburgkii (Benth.) submetidas a estresse salino e aplicação de poliamina. Revista Brasileira de Plantas Medicinais, 11(1), 63-70. http://dx.doi.org/10.1590/S1516-05722009000100011.

Brasil. Ministério da Agricultura, Pecuária e Abastecimento. (2009). Regras para análise de sementes (399 p.). Brasília: MAPA/ACS.

Canuto, D. S. O., Silva, A. M., Moraes, M. L. T., \& Resende, M. D. V. (2016). Estabilidade e adaptabilidade em testes de progênies de Myracrodruon urundeuva sob quatro sistemas de plantio. Cerne, 22(2), 171-180. http://dx.doi.org/10.1590/01047760201622021978.

Černý, M., Habánová, H., Berka, M., Luklová, M., \& Brzobohatý, B. (2018). Hydrogen peroxide: its role in plant biology and crosstalk with signalling networks. International Journal of Molecular Sciences, 19(9), 2812. PMid:30231521. http://dx.doi.org/10.3390/ijms19092812.

Costa, M. S., Ferreira, K. E. B., Botosso, P. C., \& Callado, C. H. (2015). Growth analysis of five Leguminosae native tree species from a seasonal semidecidual lowland forest in Brazil. Dendrochronologia, 36, 2332. http://dx.doi.org/10.1016/j.dendro.2015.08.004.

Diniz, R. P., Von Pinho, I. V., Paniago, B. D. C., Von Pinho, E. V. D. R., Dos Santos, H. O., Von Pinho, R. G., \& Caldeira, C. M. (2018). Qualidade fisiológica e expressão de alfa-amilase em sementes de milho produzidas em condições de estresse salino e hídrico. Revista Brasileira de Milho e Sorgo, 17(1), 3748. http://dx.doi.org/10.18512/1980-6477/rbms.v17n1p37-48. 
Edmond, J. B., \& Drapalla, W. J. (1958). The effects of temperature, sand and soil, and acetone on germination of okra seeds. Anais da American Horticutural Science, 71, 428-434.

Ferreira, D. F. (2014). Sisvar: A Guide for Its Bootstrap Procedures in Multiple Comparisons. Ciência e Agrotecnologia, 38(2), 109-112. http://dx.doi.org/10.1590/S1413-70542014000200001.

Gechev, T. S., \& Hille, J. (2005). Hydrogen peroxide as a signal controlling plant programmed cell death. The Journal of Cell Biology, 168(1), 17-20. PMid:15631987. http://dx.doi.org/10.1083/jcb.200409170.

Guler, N. S., \& Pehlivan, N. (2016). Exogenous low-dose hydrogen peroxide enhances drought tolerance of soybean (Glycine max L.) through inducing antioxidant system. Acta Biologica Hungarica, 67(2), 169-183. PMid:27165528. http://dx.doi.org/10.1556/018.67.2016.2.5.

Hernández-Barrera, A., Velarde-Buendía, A., Zepeda, I., Sanchez, F., Quinto, C., Sánchez-Lopez, R., Cheung, A. Y., Wu, H. M., \& Cardenas, L. (2015). Hyper, a hydrogen peroxide sensor, indicates the sensitivity of the Arabidopsis root elongation zone to aluminum treatment. Sensors (Basel), 15(1), 855-867. PMid:25569758. http://dx.doi.org/10.3390/s150100855.

Javed, R., Yücesan, B., \& Gurel, E. (2018). Hydrogen peroxide-induced steviol glycosides accumulation and enhancement of antioxidant activities in leaf tissues of Stevia rebaudiana Bertoni. Sugar Tech, 20(1), 100-104. http://dx.doi.org/10.1007/s12355-017-0521-y.

Kilic, D., \& Kahraman, A. (2016). The mitigation effects of exogenous hydrogen peroxide when alleviating seed germination and seedling growth inhibition on salinity-induced stress in Barley. Polish Journal of Environmental Studies, 25(3), 1053-1059. http://dx.doi.org/10.15244/pjoes/61852.

Li, J. T., Qiu, Z.-B., Zhang, X.-W., \& Wang, L.-S. (2011). Exogenous hydrogen peroxide can enhance tolerance of wheat seedlings to salt stress. Acta Physiologiae Plantarum, 33(3), 835-842. http://dx.doi.org/10.1007/s11738-010-0608-5.

Lorenzi, H. (2008). Árvores brasileiras:manual de identificação e cultivo de plantas arbóreas do Brasil (5. ed.). Nova Odessa, SP: Instituto Plantarum.

Lucchese, J. R., Bovolini, M. P., Hilgert, M. A., Brose, C. B., Avrella, E. D., \& Lazarotto, M. (2018). Estresse salino e hídrico na germinação e crescimento inicial de plântulas de Toona ciliata M. Roem. var. australis. Ciência Florestal, 28(1), 141-149. http://dx.doi.org/10.5902/1980509831633.

Maguire, J. B. (1962). Speed of germination-aid in selection and evaluation for seedling emergence vigor. Crop Science, 2(2), 176-177. http://dx.doi.org/10.2135/cropsci1962.0011183X000200020033x.

Marcos Filho, J. (2015). Fisiologia de sementes de plantas cultivadas (2. ed., 660 p.). Piracicaba: FEALQ.

Niu, L., \& Liao, W. (2016). Hydrogen peroxide signaling in plant development and abiotic responses: crosstalk with nitric oxide and calcium. Frontiers in Plant Science, 7, 230. PMid:26973673. http://dx.doi.org/10.3389/fpls.2016.00230.

Oliveira, F. A., Guedes, R. A. A., Gomes, L. P., Bezerra, F. M. S., Lima, L. A., \& Oliveira, M. K. T. (2015). Interação entre salinidade e bioestimulante no crescimento inicial de pinhão manso. Revista Brasileira de Engenharia Agrícola e Ambiental, 19(3), 204-210. http://dx.doi.org/10.1590/18071929/agriambi.v19n3p204-210.

Oliveira, G. M., Matias, J. R., Silva, P. P., Ribeiro, R. C., \& Dantas, B. F. (2014). Germinação de sementes de aroeira-do-sertão (Myracrodruon urundeuva Fr. All.) e mororó (Bauhinia cheilantha (Bong) Stend.) em diferentes condutividades elétricas. Revista Sodebras, 9(104), 70-73.

Oliveira, R. (2019). Pré-tratamento com peróxido de hidrogênio em sementes de soja induz tolerância ao estresse por déficit hídrico (Dissertação de mestrado). Universidade Estadual Paulista, Jaboticabal.

Pereira, P. S., Barros, L. M., Brito, A. M., Duarte, A. E., \& Maia, A. J. (2014). Uso da Myracroduon urundeuva Allemão (aroeira do sertão) pelos agricultores no tratamento de doenças. Revista Cubana de Plantas Medicinales, 19(1), 51-60.

Salisbury, F. B., \& Ross, C. W. (1992). Plant physiology (4. ed.). Belmont: Wadsworth.

Schossler, T. R., Machado, D. M., Zuffo, A. M., Andrade, F. R., \& Piauilino, A. C. (2012). Salinidade: efeitos na fisiologia e na nutrição mineral de plantas. Enciclopédia Biosfera, 8(15), 1564-1578.

Sies, H. (2017). Hydrogen peroxide as a central redox signaling molecule in physiological oxidative stress: oxidative eustress. Redox Biology, 11, 613-619. PMid:28110218. http://dx.doi.org/10.1016/j.redox.2016.12.035.

Taiz, L., Zeiger, E., Moller, I. M., \& Murphy, A. (2017). Fisiologia e desenvolvimento vegetal (6. ed.). Porto Alegre: Artmed

Talbi, S., Romero-Puertas, M. C., Hernández, A., Terrón, L., Ferchichi, A., \& Sandalio, L. M. (2015). Drought tolerance in a Saharian plant Oudneya africana: role of antioxidant defences. Environmental and Experimental Botany, 111, 114-126. http://dx.doi.org/10.1016/j.envexpbot.2014.11.004. 
Verma, G., Mishra, S., Sangwan, N., \& Sharma, S. (2015). Reactive oxygen species mediate axis-cotyledon signaling to induce reserve mobilization during germination and seedling establishment in Vigna radiata. Journal of Plant Physiology, 184, 79-88. PMid:26241759. http://dx.doi.org/10.1016/j.jplph.2015.07.001.

Wojtyla, L., Lechowska, K., Kubala, S., \& Garnczarska, M. (2016). Different modes of hydrogen peroxide action during seed germination. Frontiers in Plant Science, 7, 66. PMid:26870076. http://dx.doi.org/10.3389/fpls.2016.00066.

Authors' contributions: MHBSR: data curation, formal analysis, investigation, project administration, writing original draft, writing, methodology - review \& editing; JNS: data curation, formal analysis, investigation, project administration, writing - original draft, writing, methodology - review \& editing; EUA: formal analysis, investigation, writing - review \& editing, conceptualization, methodology, project, supervision, validation; RLAB: formal analysis, investigation, writing - review \& editing, conceptualization, methodology, project, supervision, validation. 